\title{
An investigation into the commercialisation of initiation schools: A case of Eastern Cape, South Africa
}

\begin{tabular}{|c|c|}
\hline $\begin{array}{l}\text { Authors: } \\
\text { Tsetselelani D } \\
\text { Pfarelo E. Ma } \\
\text { Stewart L. Ku } \\
\text { Lucky Vuma }^{1} \\
\text { Joshua Mawe }\end{array}$ & $\begin{array}{l}\text { Mdhluli }^{1} \text { (D) } \\
\text { shidze } \\
\operatorname{ara}^{2} \text { (D) } \\
\text { D } \\
\mathrm{e}^{2} \text { (D) }\end{array}$ \\
\hline $\begin{array}{l}\text { Affiliations: } \\
{ }^{1} \text { Department } \\
\text { Political Studi } \\
\text { of Humanitie } \\
\text { of Limpopo, } \mathrm{F} \\
\text { South Africa }\end{array}$ & $\begin{array}{l}\text { f Cultural and } \\
\text { es, Faculty } \\
\text { University } \\
\text { olokwane, }\end{array}$ \\
\hline $\begin{array}{l}{ }^{2} \text { Department } \\
\text { Studies, Facul } \\
\text { and Social Sci } \\
\text { University of } \\
\text { Thohoyandou }\end{array}$ & $\begin{array}{l}\text { African } \\
\text { y of Human } \\
\text { lences, } \\
\text { South Africa }\end{array}$ \\
\hline $\begin{array}{l}\text { Correspondin } \\
\text { Tsetselelani N } \\
\text { tsetselelani@ }\end{array}$ & $\begin{array}{l}\text { g author: } \\
\text { dhluli, } \\
\text { smail.com }\end{array}$ \\
\hline $\begin{array}{l}\text { Dates: } \\
\text { Received: } 23 \\
\text { Accepted: } 31 \\
\text { Published: } 30\end{array}$ & $\begin{array}{l}\text { May } 2020 \\
\text { Aug. } 2020 \\
\text { July } 2021\end{array}$ \\
\hline $\begin{array}{l}\text { How to cite t } \\
\text { Mdhluli, T.D., } \\
\text { Kugara, S.L., } \\
\text { Mawere, J., } 2 \\
\text { investigation } \\
\text { commercialis } \\
\text { initiation sch } \\
\text { Eastern Cape, } \\
\text { HTS Teologies } \\
\text { Theological St } \\
\text { a6157. https: } \\
\text { 10.4102/hts.V }\end{array}$ & $\begin{array}{l}\text { is article: } \\
\text { Matshidze, P.E., } \\
\text { uma, L. \& } \\
21 \text {, 'An } \\
\text { nto the } \\
\text { tion of } \\
\text { ols: A case of } \\
\text { South Africa', } \\
\text { e Studies/ } \\
\text { udies } 77(2), \\
\text { /doi.org/ } \\
77 \text { i2.6157 }\end{array}$ \\
\hline $\begin{array}{l}\text { Copyright: } \\
\text { (C) 2021. The } \\
\text { Licensee: AOS } \\
\text { is licensed un } \\
\text { Creative Com } \\
\text { Attribution Lic }\end{array}$ & $\begin{array}{l}\text { uthors. } \\
\text { IS. This work } \\
\text { ler the } \\
\text { nons } \\
\text { ense. }\end{array}$ \\
\hline Read online: & \\
\hline 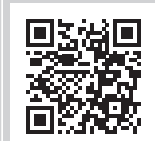 & $\begin{array}{l}\text { Scan this QR } \\
\text { code with your } \\
\text { smart phone or } \\
\text { mobile device } \\
\text { to read online. }\end{array}$ \\
\hline
\end{tabular}

This study investigated the commercialisation of initiation schools. It is argued that the economic hardships and lack of employment have led to some people resorting to any way of living merely for financial gain. The specific objectives were to determine and assess the regulations that govern the opening and running of initiation schools and to determine the palliatives that can curb commercialisation of initiation schools. The research was based on sociocultural theory and used a qualitative research design. The data collection methods used included secondary sources, focus group discussions and face-to-face interviews. The outcomes were that initiation schools are open to abuse by opportunistic unemployed people and some who are employed who want to add to their meagre wages so as to make a living, thereby crippling and undermining a cultural practice that is highly esteemed. The study recommends effective indigenous knowledge management to curb the unethical practices of commercialisation of initiation schools. Furthermore, strategies should be adopted to document this knowledge and formulate policies that will govern it.

Contribution: In line with the journal scope, this article focuses on the African Tradition Religion practice of initiation schools. This subject matter is multi-disciplinary and it covers how the sacred practice has been defiled through commersialisation and deviation from its original intent.

Keywords: initiation rites; male circumcision; indigenous knowledge systems; African value systems; customary law practices.

\section{Introduction}

Male circumcision is the most established and most customary surgery done in young men; it is performed all through the world for traditional, clinical, ritual and cosmetic reasons. Among Jews and Muslims, circumcision is a religious ritual that is performed on male children around age seven; it is performed rarely among other religions. Among Africans, male circumcision is common, but others use it as a strategy for the prevention of human immunodeficiency virus (HIV) and acquired immune deficiency syndrome (AIDS). Some communities that no longer perform circumcision are interested in doing it as an HIV/AIDS prevention strategy. In South Africa (SA) male circumcision is part of an initiation: it is a rite of passage marking the transition from boyhood to manhood. Since time immemorial, Indigenous Knowledge System (IKS) were a necessary tool to administer serenity, harmony and order in Africa.

This IKS was defined by Dixon (2005:3) as 'traditional, cultural, local and community knowledge'. South African academic institutions and the government have recognised the importance of IKSs in the development of the country. For instance, in SA, traditional kings, chiefs and medicinal healers are recognised for their value in society through legislation. In addition, Nyota and Mapara (2008:14) also labelled it as 'traditional knowledge' (TK) and/or 'indigenous traditional knowledge' (ITK). This IKS formed the bedrock of almost all African people, and every activity of their welfare was centred upon it. The study of IKSs demonstrates that they manifest themselves through diverse outlets: cultural practices, traditional beliefs or religion, agricultural activities, food, linguistics, medicine and so on.

Although some IKSs still prevail in Africa, most of these systems have failed to stand the test of time. Others are gravitating towards extinction. Despite the extinction of some, most cultural practices of African peoples seem deeply embedded in the psyche of the majority of them. Some of these cultural practices that have stood the test of time include initiation rites, the worship of ancestors, customary marriages and the paying of lobola. In most African countries, initiation

Note: Special Collection: Social Memory Studies, sub-edited by Christina Landman (University of South Africa) and Sekgothe Mokgoatšana (University of Limpopo). 
ceremonies are performed as rites of passage into new stages of life. These ceremonies are done for both males and females as a way of transitioning from childhood to adulthood. This cultural practice is typically a public announcement of the girl or boy's eligibilities for adulthood and marriage. Almost every culture in the world ritualises the important milestones that their people go through throughout their lives (Guba \& Lincoln 1981:26). In terms of the IKSs in most African countries, this cultural practice is usually done through male and female circumcision.

In numerous African social orders, circumcision is done for cultural reasons as a custom and a transitional experience into masculinity (Makgopa 2007:66). Circumcision during initiation is typically performed in a non-clinical setting by a traditional provider with no formal medicinal training. Male circumcision is defined by the medical dictionary as the surgical removal of the end of the foreskin of the penis. Some authorities suggest that circumcision is correlated with a decreased danger of HIV infection, urinary tract infection, sexually transmitted disease and penile carcinoma (Makgopa 2007). On the contrary, some authorities also dispute these views and opine that the procedure may have adverse effects on sexual, emotional or psychological health (Leclerc-Madlala 2002:3). When completed as a transitional experience into masculinity, circumcisions are mainly performed on adolescents or young men (Win 2004:16). However, some people in East Africa do not go to initiation schools, for example, the Luo of Western Kenya. Batterham et al. (2006:14) postulates that among the Kikuyu people of Kenya and the Maasai people of Kenya and Tanzania, initiation schools have been the element of the education programme that taught tribal beliefs, practices, culture and value system to the youth.

In SA, traditional practices such as circumcision as initiation are practised by indigenous knowledge holders (IKHs) and are passed on from one generation to the next (Makopa 2005:66). Furthermore, circumcisions are performed by different tribes on young boys and grown-ups as a passage from adolescence to manhood. In the past few years this tradition has been questioned and criticised by concerned individuals and media reports. The media has reported many illegal initiation schools being run by unscrupulous individuals who are not upholding the sanctity of this cultural practice but who are just in it for financial gain. This results in many medical complications and even the subsequent death of initiates. Among the Xhosa people in Eastern Cape, circumcision as initiation is highly esteemed and commonly adhered to. However, numerous reports about how unscrupulous practitioners are mushrooming have been of great concern.

South Africa still accepts and incorporates male initiation schools that include circumcision as a cultural practice and as an additional HIV prevention strategy. However, some unscrupulous individuals or groups of people form initiation schools for personal financial gain at the expense of this cultural practice. It seems likely that economic hardships and the lack of employment has led to some people resorting to any way of earning a living. In addition, some university graduates who are unemployed have nothing to do and use their acquired knowledge to professionally do some unethical things just to make a living. As a result, some of these unscrupulous graduates and others are involved in setting up these 'initiation schools'. A long time back, the formation of initiation schools was regarded as sacrilege because it involved the calling of ancestors. However, nowadays some people disregard the cultural value and see it as an opportunity for financial gain. Consequently, initiation schools are open to abuse by opportunistic unemployed people and some who are employed but who want to add to their meagre wages so as to make a living, thereby crippling and undermining a cultural practice that is highly esteemed.

\section{Literature review}

Aitken and Herman (2009) contend that a literature review is a critical summary of the published research writing applicable to the issue under study. Its motivation is to create familiarity with the ebb and flow of thinking and justify future research into previously overlooked or understudied areas.

This study explored how initiation schools are used for financial gain by some unscrupulous people in Mthatha, Eastern Cape, by conducting a literature review. Circumcision is the oldest and most widespread surgical procedure in the world. There have been references to circumcision across diverse cultures and religions. It is frequently carried out by traditional surgeons, who surgically remove the foreskin of the penis. The cutting of the foreskin by a surgeon varies with the practice of different ethnic groups (Makgopa 2007:24). The literature review in this study examined the following topics: the role of initiation schools, circumcision during initiation as an act of religious dedication, the IKS perspective on initiation schools and complications associated with circumcision at initiation schools.

\section{The role of initiation schools}

Dean (2010:2) states that circumcision is practical for cultural and traditional purposes. Dubois et al. (2007:735) also note that depictions of circumcision were found in wall paintings in the Egyptian temples dating back to $2300 \mathrm{BC}$. The circumcision procedure in the wall paintings depicted the cutting of the foreskin or the whole foreskin. Dwane (1979:19) notes that circumcision is important for health reasons. He also adds that it is used as a strategy for HIV prevention. It is believed that when men are circumcised they have lower chances of being infected by sexually transmitted diseases (STDs). Some researchers submit that when one is circumcised, the risk of acquiring HIV infection drops to $60 \%$. According to Madlala (2001:13), other tribes no longer observe circumcision as a cultural practice but do it as a means of HIV prevention. Mehtar and Faas (2001:6) argue that in cases where is used as a rite of initiation, it is an essential step in the transformation of a boy into a man. 
According to Dean (2002:2), circumcision is observed by many religious groups such as Judaism, Islamic, Christianity and many other African traditional religions (ATRs). Moreover, Dubois et al. (2007:737) state that it is closely associated with the rite of passage to manhood in religion. In Judaism, according to Dean (2010:1), circumcision dates back to the Old Testament in Genesis (17:10-14), wherein God made a covenant with Abraham and his descendants. In Judaism, circumcision is performed by a religious mohel 8 days after birth. Afterwards, the family and friends celebrate.

In Islamic regions, circumcision is practised as part of Sharia, which is based on the Holy Koran. The Hadith (narrative record of the sayings of Mohammed and his companion) and Sunnah (the way of life prescribed as normative in Islam) are in agreement as sources of Islamic law. Circumcision does not appear anywhere in the Koran but does, however, have the status of Sunnah. Dean (2010:6) regards circumcision as obligatory, whereas others regard it as recommended because it is Sunnah. The practice of circumcision in Islam is argued to be obligatory.

Makgopa (2007:22) postulates that traditional cultural practices like circumcision echo the values and convictions held by people from a community for a period, and they are passed from generation to generation. Each social group on the planet has explicit traditional cultural practices. In SA, these include initiation, whereby boys are taught to grow in a good way and to become future heads of families. Furthermore, initiation is performed in the winter season, when the schools are closed and boys have enough time to go and attend it and socialise during that period. The idea of culture is fundamental for understanding the extent of cultural rights (Airhihenbuwa 1995:38).

Dean (2010:2) opines that initiation has been a thorny issue because of those who disagree with the practice who have been witnessed among families and communities. The present researcher submits that justice has been done on the role of initiation schools. However, the authors just gave a narrative of its role without seeking the essence of restoring and safeguarding dignity of initiation schools. Moreover, African knowledge and African value systems are grounded on the realisation that much of the knowledge production processes about Africa, and for Africa, have been documented with the possibility of misrepresentation and misinformation. In that regard, this research seeks to explore unscrupulous activities at initiation schools that are merely for monetary gain at the expense of the cultural practice of circumcision.

\section{Indigenous knowledge system perspective on initiation schools}

Bakwesegha (2007:52) critically examined SA's process of cultural transformation through quizzing the IKSs' policy framework. In this thesis, the researcher advocated that the government should prioritise cultural initiatives for effective social transformation in communities. Furthermore, she submitted that the SA government should also address social imbalances and infringements and not merely put their focus and commitment on political and economic ills. With regard to this transformation, Bakwesegha (2007:57) assessed the degree to which the social and cultural significance was being trailed and the effectiveness of constitutional and legislative reform measures to meet the established IKS policy framework. In the study, the researcher observed that the development mechanism designed to combat diverse aspects of violence is ineffective, largely as a result of a lack of engagement with critical elements of IKSs, namely, epistemology.

Initiation schools are viewed as educational institutions where initiates are educated about courtship, marriage negotiations, their social duty and how to conduct themselves as men, as well as being circumcised. Circumcision is a typical practice in numerous parts of the world; it is a premise of IKSs (Funani 1990:42). Others contend that is most likely the oldest surgery known to humankind (Mavundla et al. 1997:34).

Initiation schools should be preserved and protected as an element of IKSs. It should be noted that as an institution, initiation schools are indispensable and should be preserved by IKSs because of their value as healing centres, among others (Makgopa 2007:23). People who are constantly bothered by illnesses that do not respond to modern medical treatment are advised by traditional healers (inyaka) in consultation with their ancestors to attend initiation schools as the means to find permanent relief. In the olden days, people used to go to the initiation schools with different types of sicknesses, and they came back healed because most of the people who were responsible for initiation schools were traditional healers (Makgopa 2007:19). It is believed that some initiates went to initiation schools with sicknesses that modern treatment had failed to diagnose and/or heal, but relief was finally obtained at the initiation schools.

This research raised pertinent issues with regard to the approach presently used to undertake indigenous knowledge issues within the development paradigm. With a critical lens, it will also scrutinise the function that history has played in the contemporary conceptualisation of IKSs with a view to persuade and assist the cultural practice of circumcision. Furthermore, the researcher shall thoroughly interrogate the veracity and appropriateness of cultural development initiatives within SA.

\section{Complications associated with circumcision at initiation schools}

In the United States of America, circumcision is a commonly performed procedure (Krill, Palmer \& Palmer 2011:2458-2468). In their article, Krill et al. noted that circumcision is a moderately innocuous strategy with a generally low complication rate. They additionally 
demonstrated that the various complications are minor and can be managed without any problem. In any case, circumcision complications speak to the huge number of cases seen by paediatric urologists (Patel, Moriarty \& Brisson 2011:78). Some complications regularly require a surgical remedy, which results in critical expense to the healthcare system. Then again, serious complications are very uncommon, yet death has been reported at times (Williams, Richardson \& Bukowski 2000:27). Williams et al. (2000:140) proposed that an intensive and complete preoperative assessment, concentrating on bleeding history and birth history, is imperative with regard to cases of circumcision. Proper selection of patients dependent on age and anatomic examination as well as an appropriate clean surgical strategy are critical to predict future circumcisionrelated unfriendly occasions.

Latifoğlu et al. (1999:85-88) give an assessment of the complications that are mainly associated with the cultural practice of circumcision, the most widely recognised operation performed on males. In their work, they note convincingly that despite the fact that this operation is not in fact technically difficult, it is accompanied by indisposition and can bring about complications extending from paltry to tragic (Williams \& Kapila 1993:37). They contend that this operation, regardless of whether it is done for ritualistic, religious or medical reasons, ought to be performed by a completely trained surgeon utilising an authentic technique; sufficient use of clean agents; complete partition of the internal preputial epithelium from the glans; denoting the skin to be removed toward the start of the operation; cautious consideration regarding the child's voiding inside the initial 6-8 h after circumcision; and removal or replacement of the dressings on the day following circumcision.

According to Alving and Matya (2005:19), the traditional cultural practice of circumcision in SA has indeed been a contentious one for some years. The debate now has generated considerable controversy on whether it should continue or not because of the complications that are taking place in the initiation schools. The present researcher will objectively examine whether commercialisation of the initiation schools is one of the major problems related to the death rate at the initiation schools. The researcher will also evaluate the lack of discipline of initiates who ignore the instructions from traditional surgeons or guardians. In addition, the poor health and poor infrastructure reported by the United Nations AIDS/World Health Organisation (UNAIDS/WHO 2010:2) will be explored to examine how they exacerbate the vulnerability of the initiates living under such conditions, thus covering a gap left.

\section{Commercialisation of culture}

Commercialisation of the rituals of initiation is one of the key challenges that the world is facing. According to Mabotse (1995:29), the progression of time and presentation of the cash economy in African transactions and undertakings has brought more risk to cultural practices. In the same manner, initiation has not escaped the effects of commercialisation and abuse by others. For instance, circumcision was a procedure performed in the past by older people; it is now expanding and being taken up by more youthful men. A portion of these youthful surgeons do not comprehend proper dressing techniques and the procedures; consequently, some of them are guilty of negligence in the area of cleanliness (Menjies 1998:42). Before, the practitioners were observed, as they were elder members of the community.

Building from the foundations laid down, the current research seeks to explore the African value systems with regard to circumcision. The researcher contends that nowadays young men, often unemployed, undertake circumcisions for financial reward (Menjies 1998:12). These young traditional surgeons and nurses are blamed for charging cash rather than just accepting the appreciation of the initiates and payment only as a token of appreciation. Thus, this study will cover the gap in the research about whether some of these youthful traditional surgeons and nurses no longer offer their services as a traditional contribution or commitment but are just money mongers.

\section{Theoretical framework}

The study of initiation schools was informed by sociocultural theory, which is the brainchild of Lev Vygotsky ([1931]1997:4). Sociocultural theory stresses the bond that exists between developing people and the cultural practices they subscribe to. Vygotsky succinctly states that an individual's growth can be understood by studying his or her cultural practices. Thus, examining the cultural practice of circumcision informs the researcher of how people behave and why some unscrupulous practices that are deemed are ethical persist under the noses of observers. The theory outlined shall be discussed in detail in conjunction with the IKS perspective.

\section{Methodology}

The researcher used the following instruments: desk-based research, face-to-face interviews and thematic data analysis. These research instruments are discussed below.

\section{Desk-based research}

Desk-based research involves an in-depth descriptive analysis of the primary and secondary sources. In this regard, the researcher analysed textbooks, journals and articles, newspaper reports and scholarly materials from the Internet.

\section{Face-to-face interviews}

Bless, Higson-Smith and Kagee (2006:23) argue that an interview includes direct contact with a participant, who is asked to answer questions relating to the research question. 
The researcher used face-to-face interviews to gather information. Unstructured interviews were carried out with traditional healers, traditional surgeons of initiation schools, traditional leaders and parents. The participants were selected purposively and through snowballing.

\section{Data analysis}

Thematic analysis was conducted. The themes used were drawn from the prominent issues discussed during the data collection phase. This approach was selected because it is the standard or generally accepted method of analysing qualitative data.

\section{Findings}

The findings of the study are discussed under the following themes.

\section{Commercialisation of initiation schools}

There was a broad view among the participants that there has been a mushrooming of initiation schools that are neither approved nor monitored. The vast majority of these are found in the townships, and according to many of the submissions they do not adhere to the cultural codes or the cultural practice of establishing schools in secluded areas, a long way from communities. One of the communities' essential concerns, which is likewise associated with the reason for the significant number of deaths in the schools, is the large-scale commercialisation of the initiation schools.

The researcher asked the respondents whether initiation schools are now being commercialised or not. Most parents indicated that the traditional surgeons seemed more concerned with receiving money than the performance of the actual practice. Furthermore, most people were in agreement that the payment of money for the acceptance of the initiates was now obligatory and compulsory, despite the parents' financial status. Initiates have also been reported to be excluded from initiation schools for failing to pay the admission fee. On the contrary, some traditional leaders indicated that the money collected was not for personal use by the traditional surgeons but was for the provisions used for the entire school session. Although some agreed with the views of the traditional leaders, some traditional surgeons and leaders also indicated that it was also part of their remuneration.

There was, however, an outcry from most respondents, noting that some initiation schools were in a sorry state and providing poor services, which made their children vulnerable. They complained that it was not worth the money that they paid for their children to be admitted to these schools. Furthermore, some respondents indicated that after the winter schools, the traditional surgeons seemed richer than ever and would often be drunk, some even buying new goods with their money.
As if that was not enough, some respondents indicated that untrained personnel were opening initiation schools. They mentioned three significant males who were engaged with key aspects of male circumcision. These included the surgeon (ingcibi), the traditional nurse (ikhan katha) and the anointer (umthambisi). As indicated by the respondents, these individuals all must be of acceptable social standing and carry out their responsibilities as a service to their communities. Previously, it was expected that parents would offer portions of the meat slaughtered during initiation to the surgeon and the traditional nurse as a sign of appreciation. This practice has changed over time and is best captured by the former Eastern Cape health minister, Dr Bevan Goqwana (2015), who bemoaned that:

The main problem is that the whole thing has now been commercialised and people are making money out of the tradition. (p. 6)

Moreover, the majority of parents noted that the fees for attending initiation schools were too high in Mthatha. Other respondents did not mince words but noted that the surgeons and traditional assistants (nurses) demanded hard cash and/ or a combination of cash and alcohol as remuneration. Surprisingly, some surgeons and traditional nurses were on record as charging an amount ranging from R100 to R200 per initiate. Fees of R300 or more per service have been reported. In some isolated areas of the Eastern Cape Province, reports succinctly indicated that fees of R300 or more were charged per initiate for services rendered. This form of commercialisation surrounding performance of a sacred ritual is blamed for many of the atrocities (injuries and deaths) that occur in modern times. The proliferation of initiation schools is no doubt now an acute daily agony as the rise in the number of people purporting to be expert traditional surgeons or expert traditional nurses is a signal or indicator of a strong and deeply entrenched challenge to the ritual. This increase has resulted in stiff competition and charging of unreasonable fees for attendance at initiation schools. According to tradition and the prescribed rules, the circumciser (ingcibi) is expected to learn the rare sacrosanct skill from a knowledgeable relative or a qualified and reputable initiated teacher, as an apprentice. The existing state of affairs, however, is not good tidings, especially for organic intellectuals who yearn, at least in their rhetoric, for a return to the 'old ways' of conducting the ritual in its unadulterated form.

\section{Regulations that regulate and govern the running of initiation schools}

A meticulous assessment of the submissions given appears to suggest that one of the thorny issues regarding the running of the initiation schools is the set-up and day-to-day running of the schools. The study participants contended that the deeply entrenched traditional systems and processes of setting up initiation schools had either been distorted and/or had been totally compromised - 'abrogated by disuse'. For anyone to open koma without seeking the authority and 
permission of traditional leaders is unheard of and tantamount to anathema in terms of the long-standing tradition. In line with the latter, the traditional communities vehemently maintained that an existing and properly endowed traditional leader, in consultation with the traditional council, is the only indigenous authority and voice in matters of the opening and running of initiation schools. Even though the provincial department does not have legislation on circumcision, there are municipal by-laws that govern the practice. Numerous provinces have enacted provincial legislation that governs circumcision, such as the Eastern Cape Application of Health Standards in Traditional Circumcision Act (no. 5 of 2001), the Free State Initiation School Health Act (no. 1 of 2004) and the Limpopo Province Circumcision Schools Act (no. 6 of 1996).

Ever since the enactment of the Free State Initiation School Health Act of 2004, one would presume that most communities are conversant with the slightest provisions contained in it. It emerged as a shock from the data collected from FGDs and semi-structured interviews that many community members are not aware of a single provision of the law regarding the opening and running of initiation schools'. It was unearthed that most of the community members had never heard about the law relating to initiation schools and circumcision. In addition, very few participants in the FGD claimed to have heard it mentioned on the radio and/or read of it. When the respondents who said that they knew what the law said were asked what it stated, some said that the act stated that nobody should open an initiation school without the consent of the relevant authorities.

In some FGDs, respondents opened up and admitted that they did not know about any of the provisions in the act or what it said. On the contrary, a few of the participants in the FGDs maintained that they were familiar with the provisions of the act. Some of the middle-aged community members seemed knowledgeable compared to the elderly. This may be ascribed to the fact that most of the middle-aged community members had attended school and were literate enough to read literature.

When those who claimed to be familiar with the law were asked what the law entailed, they gave the following answers:

1. The initiation schools should not overcharge clients (exorbitant profits).

2. If anyone dies at the initiation schools, the police should arrest the one who caused the death.

3. At initiation schools, the practitioners there are not allowed to use the same razor blades.

The data collected succinctly pointed out that although traditional leaders steward the running of the initiation schools, some of them are not conversant with the act. It was also gathered that numerous traditional leaders who participated in this study did not handle the cases in accordance with the dictates of the law. As such, they generally feared to challenge the chiefs even if they erred because they were regarded as custodians of this practice. Some of the chiefs self-assuredly alleged that there existed no law or rules addressing how their initiation schools were run. check their awareness of the by-laws.

The researchers also asked the informants whether the opening and running of initiation schools should be recognised by law so as to check their awareness of the by-laws. The majority of people were of the view that it should be recognised for the reason that its recognition would reduce the deaths of initiates and also prevent people from profiteering through the running of initiation schools. On the contrary, a few of the respondents were of the view that initiation schools should not be recognised by law, merely because this is a cultural practice of indigenous people. In addition, this group was of the view that the law's recognition of the practice in order to govern it would result in the continuous Westernisation of African values, thereby causing sacred things to fall into the wrong hands.

From the foregoing analysis of the responses from participants, it appeared that there is little appreciation of the law that governs initiation schools, even though it was passed. This is palpable evidence, showing that the communities have not been oriented to the law. Moreover, this lack of appreciation for what the law says elucidates to some degree why the commercialisation of initiation schools is rampant and is widely accepted by gullible community members. Conversely, those running the initiation schools for pecuniary gain are also taking advantage of the ignorance of the people to pursue their personal enrichment agendas.

\section{The opening and running of initiation schools}

Several participants echoed diverse sentiments pertaining to the thorny issue of opening and running initiation schools. Nevertheless, most participants opined that decentralised power coupled with an insurmountable lack of checks and balances failed to ensure due diligence and accountability. Those empowered by the law tend to cast a blind eye to the practice of initiation schools and excuse it from requiring policing; worse, this invites a lifethreatening loophole for so-called fly-by-night initiation schools and principals cum perpetrators, who subsequently commercialise the deeply entrenched sacred practice. It is because of this that large numbers of unqualified individuals have rushed to open initiation schools as principals. The moral decadence of their masquerade has eroded the traditional checks and balances that have existed since time immemoriall. It is against this backdrop that indigenous amateurs have now hijacked the sacrosanct responsibility of setting up schools to earn a living.

\section{Conclusion and recommendations}

In conclusion, it can be noted from the foregoing analysis that some unscrupulous people in the Eastern Cape are commercialising initiation schools because of lack of employment, weak by-laws and also to supplement their meagre salaries. Although we acknowledge the statutory 
efforts and otherwise to redeem such indispensable cultural practices, conspicuously the palliatives give the impression of remedying the conundrum of initiation circumcision in a mediocre fashion. The multiple stakeholders who have rigorously engaged with the unending encounters and problems in the initiation schools ought to be noted and a concerted attempt be made to implement solid recommendations made by these forums. It is worth noting that addressing the challenges presented by the opening and running of initiation schools calls for genuine efforts, more than just a mere piece of legislation. It ought to be put at the back of one's mind that because the traditional practice in question is shrouded with sacredness and secrecy, it therefore makes it a mammoth task to 'monitor and evaluate' the undesirable practices in such schools. Because the matter ultimately rests with communities, the government, communities and traditional leadership should form a partnership to enforce the requirements for opening initiation schools. The researchers, therefore, suggest the following recommendations.

\section{Recommendations}

The study recommends the following.

\section{Parliamentary}

The legislative framework (policy) for circumcision rites is on the provincial level; hence, observance of it is low because people seem to uphold and respect national laws. As a result, the researcher submits that a 'standard national cultural initiation legislation' ought to be established based on the provincial legislation. On that note, the national statute ought to embrace, but not be limited to, the following:

- sacrosanct and surreptitious characteristics of the practice

- security and societal safety issues

- environment and infrastructural issues

- admission age and payment matters

- eligibility criteria (age and health) for circumcision in numerous communities.

\section{House of traditional leaders}

It is unnecessary to note that the custodians of African cultural practices are traditional leaders. Against this backdrop, traditional leadership ought to be given the jurisdiction to preside over circumcision rites and initiation schools. On that note, the authors humbly propose that traditional leaders, in liaison and full traditional consultation with their council(s) and the house of traditional leaders within their jurisdiction, oversee the opening of initiation schools and the charging of fees by traditional surgeons. Because the initiation schools are within the jurisdiction of the traditional chiefs, giving them the power to oversee their opening and running will be economic and viable. Furthermore, the local house of traditional leaders ought to provide aid, on a representative basis, and adjudicate complaints and deal with exploitation and similar matters that relate directly or indirectly to initiation school disputes.

\section{Departments of Health and Social Development}

To nip the this problem in the bud, the Department of Social Development ought to have blanket responsibility for preventing disadvantaged homes and families from being taken advantage of by money-mongers and should assist them in paying initiation school fees and monitoring whether the money paid was used profitably for the benefit of initiates. On the other hand, the Department of Health should ensure that prospective initiates are subject to a series of in-depth medical check-ups before they are admitted to undergo initiation rites - especially the ritual of circumcision. This would help verify the fitness and health of initiates, who may be denied access to these schools by money-mongers, who prefer money at the expense of lives. Likewise, if an initiation school is declared null and void and forced to close, the initiates ought to be transferred to a legal initiation school to ensure that they successfully complete their circumcision rites.

\section{Acknowledgements}

The authors acknowledge the guidance and support of the Mthatha community.

\section{Competing interests}

The authors declare that they have no financial or personal relationships that may have inappropriately influenced them in writing this article.

\section{Authors' contributions}

All authors contributed equally to this work.

\section{Ethical considerations}

This article followed all ethical standards for research without direct contact with human or animal subjects.

\section{Funding information}

This research received no specific grant from any funding agency in the public, commercial or not-for-profit sectors.

\section{Data availability statement}

Data sharing is not applicable to this article as no new data were created or analysed in this study.

\section{Disclaimer}

The views and opinions expressed in this article are those of the authors and do not necessarily reflect the official policy or position of any affiliated agency of the authors.

\section{References}

Airhihenbuwa, C.O., 1995, Health and culture: Beyond the Western paradigm, Sage, New York.

Aitken, S.C. \& Herman, T., 2009, Literature review on qualitative methods and standards for engaging and studying independent children in the developing world (No. inwopa09/63), UNICEF Innocenti Research Centre, Florence, Italy. 
Alving, C.R. \& Matyas, G.R., 2005, 'Design and selection of vaccine adjuvants: Principles and practice', in The grand challenge for the future, pp. 99-118, Birkhäuser, Basel.

Bakwesegha, B.B., 2007, 'Examining South Africa's process of cultural transformation: Interrogating the Indigenous Knowledge System (IKS) policy framework', Doctora dissertation, University of Cape Town, Pretoria.

Batterham, R.L., Heffron, H., Kapoor, S., Chivers, J.E., Chandarana, K., Herzog, H. et al., 2006, 'Critical role for peptide YY in protein-mediated satiation and body-weight regulation' Cell Metabolism 4(3), 223-233. https://doi.org/10.1016/j.cmet.2006.08.001

Bless, C., Higson-Smith, C. \& Kagee, A., 2006, Fundamentals of social research methods: An African perspective, Juta and Company Ltd, London, New York.

Dean, K.C., 2010, Almost Christian: What the faith of our teenagers is telling the American church, Oxford University Press, New York, NY.

Dubois, B., Feldman, H.H., Jacova, C., DeKosky, S.T., Barberger-Gateau, P., Cummings, J. et al., 2007, 'Research criteria for the diagnosis of Alzheimer's disease: Revising
the NINCDS-ADRDA criteria', The Lancet Neurology 6(8), 734-746. https://doi. the NINCDS-ADRDA criteria', The Lan
org/10.1016/S1474-4422(07)70178-3

Dwane, S., 1979, 'Christianity in relation to Xhosa religion', Doctoral dissertation, University of London, London.

Funani, L.S., 1990, Circumcision among the ama-Xhosa. A medical investigation, Skotaville, Braamfontein, Johannesburg.

Guba, Y.S. \& Lincoln, E.S., 1981, Effective evaluation: Improving the usefulness of evaluation results through responsive and naturalistic approaches, Jossey-Bass social and behavioral science series, Jossey-Bass, San Francisco, CA.

Krill, A.J., Palmer, L.S. \& Palmer, J.S., 2011, 'Complications of circumcision', The Scientific World Journal 11, 2458-2468. https://doi.org/10.1100/2011/ 373829

Latifoğlu, O., Yavuzer, R., Demir, Y., Ayhan, S., Yenidunya, S. \& Atabay, K., 1999, 'Surgical management of penoscrotal lymphangioma circumscriptum', Plastic and Reconstructive Surgery 103(1), 175-178. https://doi.org/10.1097/00006534199901000-00028

Leclerc-Madlala, S., 2001. 'Demonising women in the era of AIDS: On the relationship between cultural constructions of both HIV/AIDS and femininity', Society in transition, 32(1), 38-46.

Leclerc-Madlala, S., 2002, 'Youth, HIV/AIDS and the importance of sexual culture and context', Social Dynamics 28(1), 20-41. https://doi.org/10.1080/ 02533950208458721

Mabotse, 1995, 'The initiates', Sunday Times, 30 July.

Makgopa, M.M., 2007, 'Inexperienced adults' reliance on extrinsic product attributes to judge the quality of major household appliances', Doctoral dissertation, University of Pretoria, Pretoria.
Mavundla, T.R., Netswera, F.G., Bottoman, B. \& Toth, F., 1997, 'Rationalization of indigenous male circumcision as sacred religious custom: Health beliefs of Xhosa men in South Africa', Journal of Transcultural Nursing 20(4), 395-404. https://doi. men in South Africa', Journal of Transc
org/10.1177/1043659609340801

Mehtar, S. \& Faas, J., 2001, 'Simple intervention to prevent post circumcision sepsis amongst Xhosa males: Short report', Southern African Journal of Epidemiology and Infection 16(1), 29-30.

Menjies, A., 1998, 'Treatment of irritable bowel syndrome with Chinese herbal medicine: A randomized controlled trial', JAMA 280(18), 1585-1589. https://doi. org/10.1001/jama.280.18.1585

Mdhluli, T.D., 2017. An examination of the challenges experienced at the male initiation schools: The selected case study of Mthatha district in the Eastern Cape Province South Africa, Maters Dissertation, University of Venda.

Nyota, S. \& Mapara, J., 2008, 'Shona traditional children's games and play: Songs as indigenous ways of knowing', The Journal of Pan African Studies 2(4), 189-202.

Patel, M.K., Moriaty, M. \& Brisson, M., 2011, 'Evaluation of epidemiology, safety, and complications of male circumcision using conventional dissection surgery: Experience at one center', Open Access Journal of Urology 3, 83. https://doi. org/10.2147/OAJU.S17913

Qoqwana, 2005, 'Summer initiation schools', Sunday World, 02 December.

Republic of South Africa (RSA), 1996, South African Schools Act 1996, No. 84 of 1996, Juta, Cape Town.

Republic of South Africa (RSA), 2001, Eastern Cape Health Standards in Traditional Circumcision Act 2001, Juta, Cape Town.

Republic of South Africa (RSA), 2004, Free State Initiation Schools Act No 1, Juta, Cape Town.

Sillitoe, P., Dixon, P. \& Barr, J., 2005. Indigenous Knowledge Inquiries, Practical Action Publishing, Warwickshire.

Vygotsky, L.S., 1931, 'Chapter 12: Imagination and creativity in the adolescent', in The Pedology of the adolescent from volume 4 of the collected works of L.S. Vygotsky, transl. F. Smolucha, Pedagogika, Moscow, 1984.

WHO/UNAIDS, 2010, Male circumcision: global trends and determinants of prevalence, safety and acceptability. World Health Organization, Geneva.

Williams, N. \& Kapila, L., 1993, 'Complications of circumcision', British Journal of Surgery 80(10), 1231-1236. https://doi.org/10.1002/bjs.1800801005

Williams, C.P., Richardson, B.G. \& Bukowski, T.P., 2000, 'Importance of identifying the inconspicuous penis: Prevention of circumcision complications', Urology 56(1), 140-142. https://doi.org/10.1016/S0090-4295(00)00601-4 